\title{
EFFECTS OF FERROUS SULFATE, INOCULUM HISTORY, AND ANIONIC FORM ON LEAD, ZINC, AND COPPER TOXICITY TO ACIDITHIOBACILLUS CALDUS STRAIN BC13
}

\author{
John E. Aston $\nmid \dagger$ Brent M. Peyton $\nmid \dagger$ Brady D. Lee, $\ddagger$ and William A. Apel $* \ddagger$ \\ $\dagger$ Department of Chemical and Biological Engineering, Montana State University, Bozeman, Montana, USA \\ $\ddagger$ Biological Systems Department, Idaho National Laboratory, Idaho Falls, Idaho, USA
}

(Submitted 23 March 2010; Returned for Revision 20 April 2010; Accepted 19 July 2010)

\begin{abstract}
The current study reports the single and combined toxicities of $\mathrm{Pb}, \mathrm{Zn}$, and $\mathrm{Cu}$ to Acidithiobacillus caldus strain $\mathrm{BC} 13$. The observed half-maximal inhibitory concentrations (IC50), $\pm 95 \%$ confidence intervals, for $\mathrm{Pb}, \mathrm{Zn}$, and $\mathrm{Cu}$ were $0.9 \pm 0.1 \mathrm{mM}$, $39 \pm 0.5 \mathrm{mM}$, and $120 \pm 8 \mathrm{mM}$, respectively. The observed minimum inhibitory concentrations (MIC) for $\mathrm{Pb}, \mathrm{Zn}$, and $\mathrm{Cu}$ were $7.5 \mathrm{mM}, 75 \mathrm{mM}$, and $250 \mathrm{mM}$, respectively. When metals were presented in binary mixtures, the toxicities were less than additive. For example, when $50 \%$ of the $\mathrm{Pb}$ MIC and $50 \%$ of the $\mathrm{Cu}$ MIC were presented together, the specific growth rate was inhibited by only $59 \pm 3 \%$, rather than $100 \%$. In addition, the presence of ferrous iron in the growth media decreased $\mathrm{Pb}$ and $\mathrm{Zn}$ toxicity to A. caldus strain $\mathrm{BC} 13$. The importance of inoculum history was evaluated by pre-adapting cultures through subsequent transfers in the presence of $\mathrm{Pb}$, $\mathrm{Zn}$, and $\mathrm{Cu}$ at their respective IC50s. After pre-adaptation, cultures had specific growth rates $39 \pm 11,32 \pm 7$, and $28 \pm 12 \%$ higher in the presence of $\mathrm{Pb}, \mathrm{Zn}$, and $\mathrm{Cu}$ IC50s, respectively, compared with cultures that had not been pre-adapted. In addition, when cells exposed to the MICs of $\mathrm{Pb}, \mathrm{Zn}$, and $\mathrm{Cu}$ were harvested, washed, and re-inoculated into fresh, metal-free medium, they grew, showing that the cells remained viable with little residual toxicity. Finally, metal chlorides showed more toxicity than metal sulfates, and studies using sodium chloride or a mixture of metal sulfates and sodium chloride suggested that this was attributable to an additive combination of the metal and chloride toxicities. Environ. Toxicol. Chem. 2010;29:2669-2675. (C) 2010 SETAC
\end{abstract}

Keywords-Acidithiobacillus Toxicity Lead Zinc Copper

Acidithiobacillus caldus is a gram-negative bacterium that oxidizes sulfur and reduced sulfur compounds for energy, and that can fix carbon dioxide as a sole carbon source [1,2]. Acidithiobacillus caldus grows from $\mathrm{pH} 1$ to 4, with optimal growth between $\mathrm{pH} 2$ and 3 , and from 32 to $50^{\circ} \mathrm{C}$, with optimal growth at $45^{\circ} \mathrm{C}$ [1]. These traits make $A$. caldus well suited for growth in many biomining systems [3-6], where recent studies suggest that it may play a significant role in metal mobilization. McGuire et al. [7] reported that microbial communities containing A. caldus were observed to leach more Fe from pyrite, arsenopyrite, and marcasite than communities without $A$. caldus [7]. Dopson and Lindstrom [8] reported that twice as much Fe was leached from arsenopyrite when an $\mathrm{Fe}$ oxidizer, Sulfobacillus thermosulfidooxidans, was cocultured with $A$. caldus, as compared with when $S$. thermosulfidooxidans was cultured alone [8]. In addition, A. caldus was observed to enhance $\mathrm{Cu}$ recovery by oxidizing $\mathrm{S}$ formed during the biomining of chalcopyrite [9]. These studies suggest an important role for A. caldus in commercial biomining; however, few direct studies of metal interactions and toxicities to A. caldus have been published.

The toxicity of metals to microorganisms has been well documented, and several general reviews have been written covering this subject [10-15]. Specific to the work presented here, multiple studies have reported that the related microorganisms, Acidithiobacillus ferrooxidans and Acidithiobacillus thiooxidans, have relatively high tolerance to $\mathrm{Zn}$ and $\mathrm{Cu}$ when presented individually [16-21] or combined [18,22]. However, toxicity studies with $A$. caldus have been limited

* To whom correspondence may be addressed (William.Apel@inl.gov).

Published online 27 August 2010 in Wiley Online Library (wileyonlinelibrary.com). to the metalloid As [23-25]. Recent work by Watkin et al. [26] compared $\mathrm{Fe}, \mathrm{Cu}, \mathrm{Zn}, \mathrm{Ni}$, and $\mathrm{Co}$ tolerances of several new isolates with those of several known strains, including A. caldus strain KU, but in-depth inhibition studies were not done [26].

The purpose of the current study was to test the single and combined toxicities of various metals to A. caldus strain $\mathrm{BC} 13$, including the effects of metal mixtures, inoculum history, metal concentration and speciation, and the use of different metal anionic forms to determine which conditions should be considered in future work with $A$. caldus strain $\mathrm{BC} 13$ and possibly other microorganisms. Specifically, the current study is a comprehensive report on the effects of $\mathrm{Pb}, \mathrm{Zn}$, and $\mathrm{Cu}$ on the growth of $A$. caldus strain BC13, including effects of single versus combined metal toxicity, effects of high ferrous iron concentrations on $\mathrm{Pb}, \mathrm{Zn}$, and $\mathrm{Cu}$ toxicity, effects of prior exposure to $\mathrm{Pb}, \mathrm{Zn}$, and $\mathrm{Cu}$, and a comparison of metal sulfate and metal chloride toxicity. Zinc and $\mathrm{Cu}$ were chosen because of their commercial relevance and ubiquity in biomining and acid-mine environments. Lead was chosen as a control test because $A$. caldus has not been identified in environments containing high levels of galena. By identifying the effects of various environmental conditions on the efficacy of these metals toward A. caldus strain BC13, this report significantly increases the current understanding of this microorganism and how the conditions of biomining and acid-mine drainage environments may affect its metal tolerance.

\section{MATERIALS AND METHODS}

Microorganism and growth conditions

Acidithiobacillus caldus strain BC13 (ATCC 51757), henceforth referred to as $\mathrm{BC} 13$, was grown in a basal salts medium [1]. The medium was autoclaved for 15 minutes at $121^{\circ} \mathrm{C}$ and 
$22 \mathrm{psi}$, and the $\mathrm{pH}$ was then adjusted to 2.5, using 6 normal sulfuric acid. A filtered $(0.2 \mu \mathrm{m})$ metal sulfate solution of $\mathrm{Pb}$, $\mathrm{Zn}$, or $\mathrm{Cu}$ was added from a stock solution. The concentrations of metal in the stock solutions were adjusted to ensure that an equal volume could be added to each flask. A filter-sterilized $(0.2 \mu \mathrm{m})$ solution of potassium tetrathionate was then added to a concentration of $5 \mathrm{mM}$, as an electron donor, and ambient carbon dioxide provided the sole carbon source. Cells preserved at $4{ }^{\circ} \mathrm{C}$ in nanopure water $(17.4 \mathrm{M} \Omega)$, with the $\mathrm{pH}$ adjusted to 3.0 using 6 normal sulfuric acid, provided the initial inoculum. Aliquots that provided initial cell densities of approximately $5 \times 10^{7}$ cells $/ \mathrm{ml}$ were used. Cells were cultured in $125-\mathrm{ml}$ Erlenmeyer flasks ( $75 \mathrm{ml}$ medium volume), fitted with foam stoppers, and shaken at $150 \mathrm{rpm}$ in a temperature-controlled incubator at $45^{\circ} \mathrm{C}$.

\section{Experimental design and statistics}

Initial growth inhibition studies were carried out at relatively large concentration intervals to roughly estimate the minimum inhibitory concentrations (MICs) of $\mathrm{Pb}, \mathrm{Zn}$, and $\mathrm{Cu}$. After this was done, more detailed experiments were carried out to quantify the inhibitory effects of each metal in the relevant concentration range. In experiments that determined the effects of ferrous iron on metal toxicity, ferrous iron was added to concentrations up to environmentally relevant conditions. Each experiment was repeated in triplicate under identical conditions, so that average values and $95 \%$ confidence intervals could be calculated for specific growth rates at each metal concentration and condition tested. To determine the half-maximal inhibitory concentrations (IC50s) and corresponding 95\% confidence intervals, linear regressions were calculated using the LINEST function in Microsoft Excel ${ }^{\circledR}$. Using this method, data points from each set of a triplicate across a range of concentrations contributed to determining the reported IC50s. No statistical confidence was assigned to the no-observable-effect concentration, lowest-observable-effect concentration, and MIC, because these values were determined graphically from average values.

\section{Determining metal toxicity}

Cell concentrations were measured by using direct cell counts at 12-h intervals with a Petroff-Hauser counting chamber (Hausser Scientific) and a phase-contrast microscope (Zeiss). To perform cell counts, an aliquot of growth medium was added to the counting chamber to volume $\left(5 \times 10^{-5} \mathrm{~mm}^{3} /\right.$ grid $)$. Cells were then counted across grids from the middle and all sides of the counting grid to account for any possible spatial variations. In more cell-dense samples, each cell in individual $0.05 \times 0.05 \mathrm{~mm}$ grids was counted until a minimum of 400 cells were counted. In less cell-dense samples, each cell in a minimum of 20 small $(0.05 \times 0.05 \mathrm{~mm})$ grids was counted. The observed specific growth rates were calculated from the resultant growth curves and used to quantify inhibition.

To determine combined metal toxicity, binary mixtures of $\mathrm{Pb}$ and $\mathrm{Zn}, \mathrm{Pb}$ and $\mathrm{Cu}$, and $\mathrm{Zn}$ and $\mathrm{Cu}$ were prepared. Concentrations were proportional to their respective MICs and, assuming additive toxicities, mixed to produce a total metal concentration proportional to an effective MIC. For example, to produce a mixture containing $\mathrm{Pb}$ and $\mathrm{Zn}$ equivalent to $50 \%$ of an effective MIC, the final growth medium would contain: $0.5 \cdot\left(\frac{\mathrm{MIC}_{\mathrm{Pb}}}{2}+\frac{\mathrm{MIC}_{\mathrm{Zn}}}{2}\right)$. Linear regressions were used to calculate expected toxicities between tested data points using the LINEST function in Microsoft Excel. From these regressions, estimated contributions toward the total effective toxicity from each metal were calculated.

Similar experiments were conducted to determine whether ferrous iron affected the toxicity of $\mathrm{Pb}, \mathrm{Zn}$, or $\mathrm{Cu}$ to $\mathrm{BC} 13$. Each metal was added to a concentration equal to its previously calculated IC50, and ferrous iron sulfate was added to concentrations of $0,25,50,75$, or $100 \mathrm{mM}$. The concentration of ferrous iron in each stock was adjusted so that an equal volume was added to each flask. Lead-, $\mathrm{Zn}$-, and $\mathrm{Cu}$-free controls were performed to determine whether ferrous iron alone affected $\mathrm{BC} 13$ in the absence of $\mathrm{Pb}, \mathrm{Zn}$, or $\mathrm{Cu}$.

\section{Determining effects of previous metal exposure}

Cells were prepared as described earlier and inoculated into growth medium containing $\mathrm{Pb}, \mathrm{Zn}$, or $\mathrm{Cu}$ concentrations equal to the previously calculated IC50. During the late-log growth phase, cells were harvested and washed as previously described, then inoculated into fresh medium containing the same metal concentration. This process was repeated three times to allow cells to adapt to $\mathrm{Pb}, \mathrm{Zn}$, or $\mathrm{Cu}$. During the fourth growth cycle, cell concentrations were measured using direct counts as described previously, and the specific growth rates were calculated.

\section{Determining metal chloride toxicity}

Cells were prepared as described previously, but metal chlorides were used instead of metal sulfates. Chloride salts of $\mathrm{Pb}, \mathrm{Zn}$, or $\mathrm{Cu}$ were introduced at initial concentrations equal to the previously calculated IC50s of the respective metal sulfate counterparts. To determine whether chloride ions contributed directly to cell inhibition, sodium chloride was added to metal-free growth media at concentrations of $0,50,100$, and $200 \mathrm{mM}$. In control experiments, lead, zinc, or copper sulfates were added to concentrations proportional to their previously calculated IC50s, and sodium chloride also was added to concentrations of $0,50,100$, or $200 \mathrm{mM}$. In these experiments, cell concentrations were measured as described previously, and specific growth rates were calculated for comparison.

\section{Modeling metal complexation and precipitation}

Visual MINTEQ (version 2.53) software was used to predict complexation and precipitation of media components using activities from the Debye-Huckel equation and the default MINTEQA2 thermodynamic database. The temperature was set to $45^{\circ} \mathrm{C}$, and the proton concentration was calculated from the $\mathrm{pH}$, which was set at 2.50. The saturation index (defined as the log of the ion activity divided by the solubility product) was used to predict metal precipitation. Compounds with a positive saturation index were set to infinite saturation, to allow for their precipitation. Each experimental medium condition tested was modeled in this manner. The statistical software MINITAB was then used to construct matrix plots and perform primary component analyses to determine relations between metal complexation and the observed specific growth rates at various metal concentrations.

\section{RESULTS}

\section{Single metal toxicity}

Figure 1a shows the effect of $\mathrm{Pb}$ concentrations on the specific growth rate of BC13. Similarly, the effects of $\mathrm{Zn}$ (Fig. 1b) and $\mathrm{Cu}$ (Fig. 1c) also are shown. Lead was the most toxic of the three metals tested, with an IC50 of $0.94 \pm$ $0.13 \mathrm{mM}$, and an MIC of $7.5 \mathrm{mM}$. An IC50 and an MIC of 

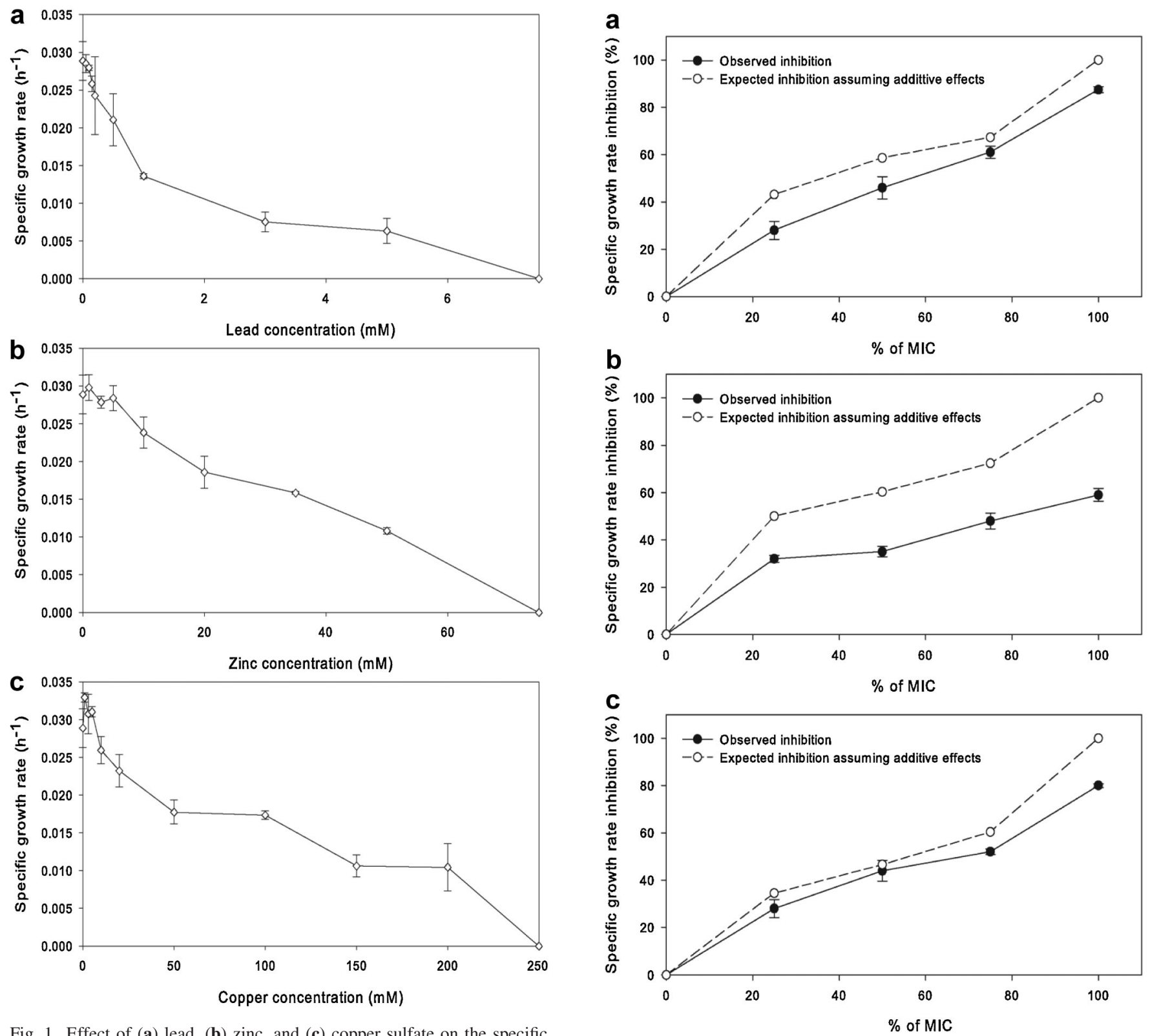

Fig. 1. Effect of (a) lead, (b) zinc, and (c) copper sulfate on the specific growth rate of Acidithiobacillus caldus strain BC13. Error bars represent $95 \%$ confidence intervals.

$39 \pm 0.5$ and $75 \mathrm{mM}$, respectively, were observed for $\mathrm{Zn}$, whereas $\mathrm{Cu}$ was the least toxic metal tested, with an IC50 and MIC of $120 \pm 8.2$ and $250 \mathrm{mM}$, respectively (Table 1).

\section{Combined metal toxicity}

To determine the combined toxicity of $\mathrm{Pb}, \mathrm{Zn}$, and $\mathrm{Cu}$, metals were presented in binary mixtures in ratios proportional to their individual IC50s. Binary metal mixtures containing ratios of $12.5,25,37.5$, and $50 \%$ of each metal's respective MIC was used. Assuming additive toxicity when mixed, the effective overall metal concentrations were then $25,50,75$, and $100 \%$ of an effective MIC. However, Figure 2 shows that the toxicities were less than additive. For example, when $25 \%$ of the $\mathrm{Pb}$ MIC was mixed with $25 \%$ of the $\mathrm{Zn} \mathrm{MIC,} \mathrm{the} \mathrm{observed} \mathrm{specific}$ growth rate was $0.016 \pm 0.001 / \mathrm{h}$, compared with a predicted specific growth rate of $0.012 / \mathrm{h}$, calculated assuming additive toxicities (Fig. 2a). Similar results were seen when $\mathrm{Pb}$ and $\mathrm{Cu}$, and $\mathrm{Zn}$ and $\mathrm{Cu}$, were mixed at varying concentrations (Fig. 2b, c).

Fig. 2. Observed inhibition compared with predicted inhibition, assuming additive toxicity, of binary mixtures of lead and zinc (a), lead and copper (b), and zinc and copper (c) to strain Acidithiobacillus caldus BC13. The $x$ axis represents the percentage of the minimum inhibitory concentration (MIC) calculated, assuming additive effects. Error bars represent $95 \%$ confidence intervals. The MIC concentrations for lead, zinc, and copper were 7.5, 75, and $250 \mathrm{mM}$, respectively.

\section{Effect of ferrous iron on metal toxicity}

Ferrous iron gave significant protection to $\mathrm{BC} 13$ from $\mathrm{Pb}$ and $\mathrm{Zn}$ toxicity. Figure 3 shows that cultures exposed to a concentration of $\mathrm{Pb}$ equal to the IC50 exhibited specific growth rates of $0.014 \pm 0.001,0.032 \pm 0.001$, and $0.030 \pm 0.001 / \mathrm{h}$ when ferrous iron was added to concentrations of 0,50 , and $100 \mathrm{mM}$, respectively. Similarly, the observed specific growth rates of cultures in the presence of the Zn IC50 were $0.016 \pm 0.001$, $0.023 \pm 0.001$, and $0.028 \pm 0.001 / \mathrm{h}$ when ferrous iron was added to 0,50 , and $100 \mathrm{mM}$, respectively. However, when this experiment was performed using $\mathrm{Cu}$, the effect was significantly decreased, as observed specific growth rates were $0.017 \pm 0.001,0.014 \pm 0.000$, and $0.019 \pm 0.001 / \mathrm{h}$ when ferrous iron was added to concentrations of 0,50 , and $100 \mathrm{mM}$, 


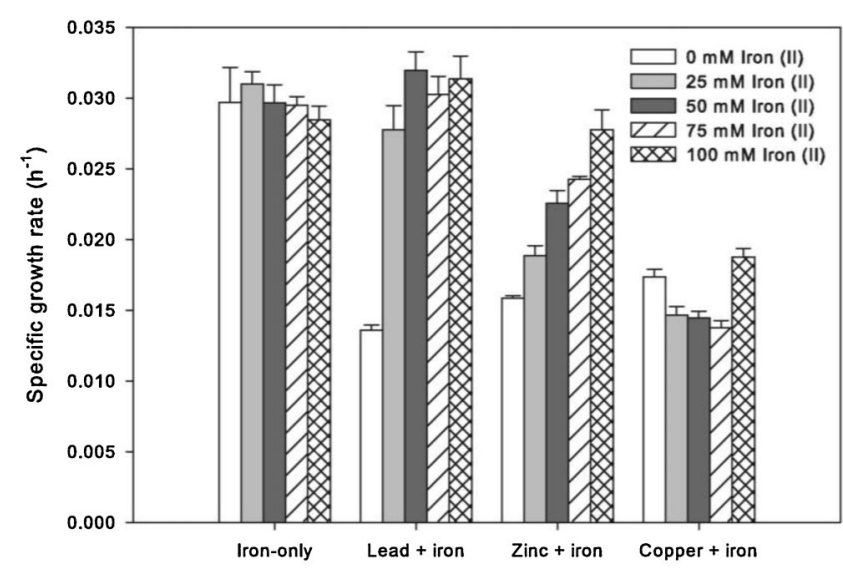

Fig. 3. The effect of ferrous iron added to concentrations of $0,25,50,75$, or $100 \mathrm{mM}$ on lead, zinc, and copper toxicity to Acidithiobacillus caldus strain $\mathrm{BC} 13$ when added at concentrations equal to the previously calculated halfmaximal inhibition concentrations $(0.94 \mathrm{mM}, 39 \mathrm{mM}$, and $120 \mathrm{mM}$ for lead, zinc, and copper, respectively). Error bars represent $95 \%$ confidence intervals.

respectively (Fig. 3). In separate control experiments, ferrous iron was added to concentrations of 0,50 , and $100 \mathrm{mM}$ with no $\mathrm{Pb}, \mathrm{Zn}$, or $\mathrm{Cu}$ added. At these concentrations, the observed specific growth rates were $0.030 \pm 0.001,0.030 \pm 0.001$, and $0.028 \pm 0.001 / \mathrm{h}$, suggesting that ferrous iron did not significantly affect the growth of BC13 by itself (Fig. 3). Visual MINTEQ predicted that more than $96 \%$ of the Fe remained as aqueous ferrous iron at the concentrations used in the current study.

\section{Effect of prior metal exposure on metal toxicity}

Figure 4 shows that the specific growth rate increased $39 \pm 11,32 \pm 7$, and $28 \pm 12 \%$ when cultures were pre-adapted, through subsequent transfers, to $\mathrm{Pb}, \mathrm{Zn}$, or $\mathrm{Cu}$, respectively. In addition to increased specific growth rates, the lag phase of cultures pre-adapted to $\mathrm{Pb}, \mathrm{Zn}$, or $\mathrm{Cu}$ decreased by 12,24 , and $48 \mathrm{~h}$, respectively (data not shown).

Figure 5 shows that cells collected from media containing the $\mathrm{MIC}$ of $\mathrm{Pb}, \mathrm{Zn}$, or $\mathrm{Cu}$ were able to resuscitate and grow in fresh, metal-free medium. After being exposed for $120 \mathrm{~h}$ to the

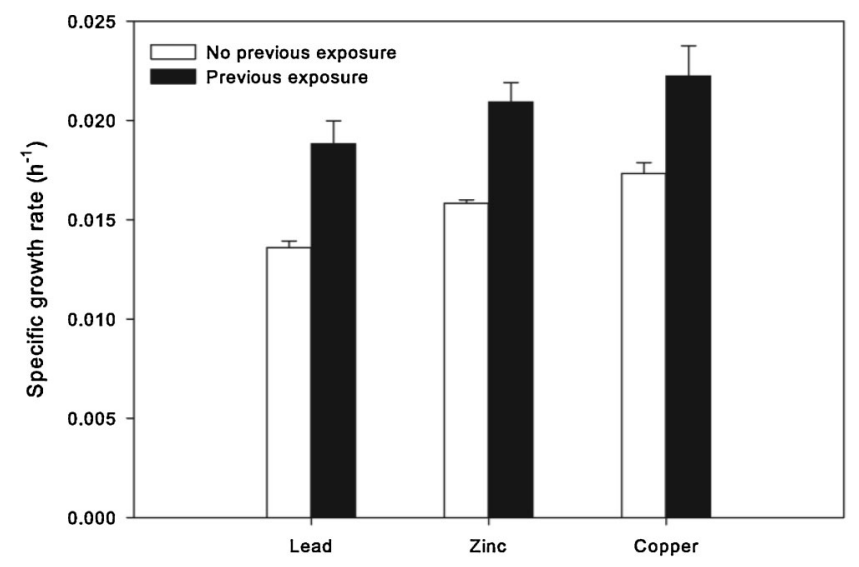

Fig. 4. Effect of prior exposure to lead, zinc, and copper on the specific growth rate of Acidithiobacillus caldus strain BC13. Cells were adapted through subsequent culturing and transfers in the presence of the halfmaximal inhibitory concentrations of lead, zinc, or copper $(0.94 \mathrm{mM}, 39 \mathrm{mM}$, and $120 \mathrm{mM}$, respectively). Error bars represent $95 \%$ confidence intervals.

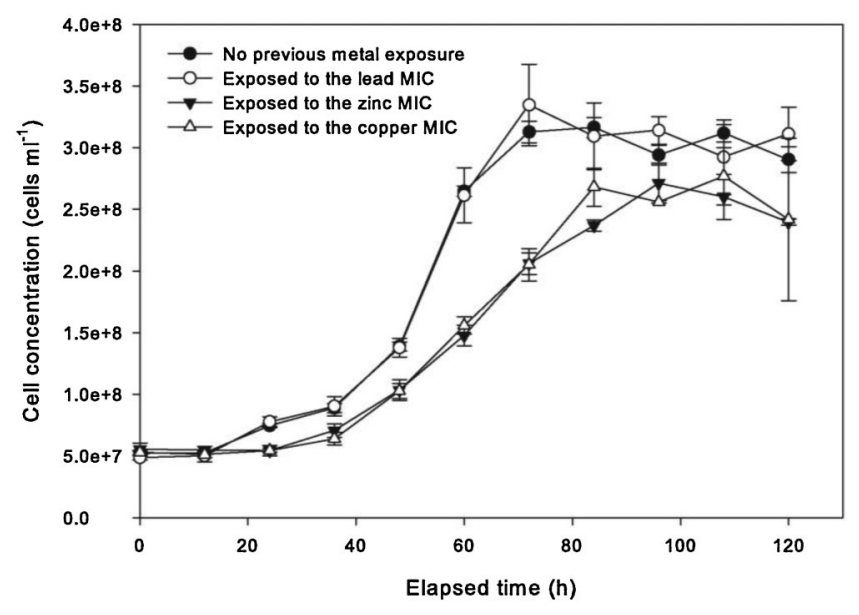

Fig. 5. Growth of Acidithiobacillus caldus strain BC13 in metal-free cultures after cells were harvested from cultures containing minimum inhibitory concentrations of lead, zinc, or copper, or 7.5, 75, and $250 \mathrm{mM}$, respectively. Error bars represent $95 \%$ confidence intervals.

MIC of $\mathrm{Pb}$, then re-inoculated into fresh, metal-free medium, cultures grew with no residual inhibition and attained a final cell concentration of $107 \pm 7 \%$ of the final cell concentration observed for cultures that had not been exposed to $\mathrm{Pb}$. However, when cells were collected from medium containing the MIC of $\mathrm{Zn}$ or $\mathrm{Cu}$ after $120 \mathrm{~h}$ of exposure, and re-inoculated into fresh, metal-free medium, the cultures grew to final cell concentrations of only $83 \pm 1$ and $83 \pm 23 \%$ of the final cell concentration observed in cultures with no prior exposure to $\mathrm{Zn}$ or $\mathrm{Cu}$, respectively. The observed specific growth rates of cells exposed to MICs of $\mathrm{Pb}, \mathrm{Zn}$, and $\mathrm{Cu}$ for $120 \mathrm{~h}$ were $0.032 \pm 0.003,0.028 \pm 0.002$, and $0.030 \pm 0.003 / \mathrm{h}$, respectively, after being re-inoculated into fresh, metal-free medium. Cells that had not been pretreated by the MICs of $\mathrm{Pb}, \mathrm{Zn}$, or $\mathrm{Cu}$ exhibited an observed specific growth rate of $0.029 \pm 0.003 / \mathrm{h}$, suggesting that there were no significant residual affects on the observed specific growth rates (data not shown).

\section{Comparison of metal chloride to metal sulfate toxicity}

Figure 6a shows that when lead, zinc, and copper chlorides were added at concentrations equal to the IC50s of their respective sulfates, the observed specific growth rates were lower than those observed for the metal sulfates. For $\mathrm{Pb}$, this difference was relatively minor, $0.012 \pm 0.001 / \mathrm{h}$ versus $0.014 \pm 0.000 / \mathrm{h}$, respectively. However, in the case of $\mathrm{Zn}$ and $\mathrm{Cu}$, the differences were more pronounced. The specific growth rate observed when zinc chloride was used was $0.012 \pm 0.001 / \mathrm{h}$, compared with $0.016 \pm 0.000 / \mathrm{h}$ when zinc sulfate was added. Similarly, the specific growth rate observed when copper chloride was added was $0.012 \pm 0.000 / \mathrm{h}$, compared with $0.017 \pm 0.001 / \mathrm{h}$ when copper sulfate was used.

The specific growth rate of $\mathrm{BC} 13$ also decreased when only sodium chloride was added to metal-free medium. When sodium chloride was added to concentrations of $0,50,100$, and $200 \mathrm{mM}$, the specific growth rates were $0.029 \pm 0.002$, $0.027 \pm 0.001,0.023 \pm 0.001$, and $0.021 \pm 0.001 / \mathrm{h}$, respectively. In other experiments, lead, zinc, and copper sulfate were added to concentrations equal to their respective IC50s, and the sodium chloride concentration was varied. The inhibition observed in these tests suggested that the metal and chloride toxicity effects are additive (Fig. 6b). 

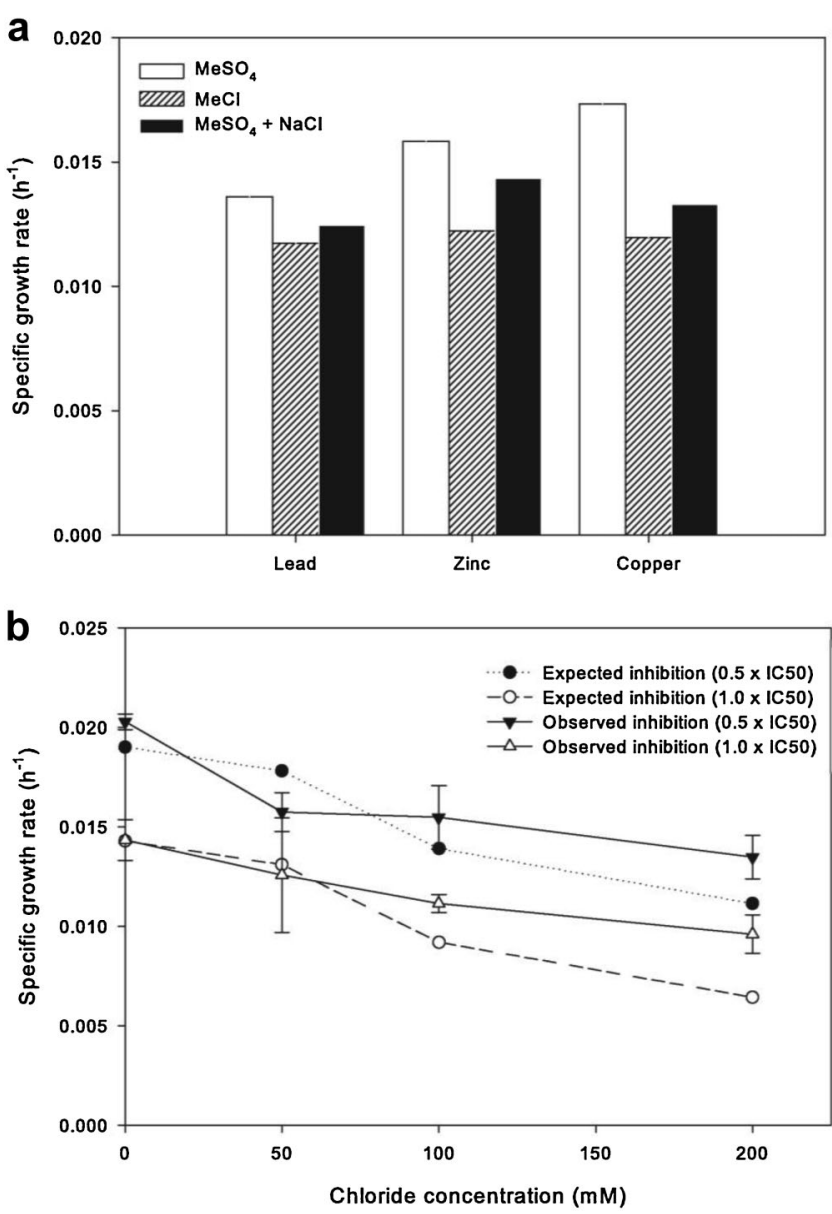

Fig. 6. (a) Effect of lead, zinc, and copper on the specific growth rate of Acidithiobacillus caldus strain BC13 when added as either metal sulfates, metal chlorides, or metal sulfates with a corresponding concentration of sodium chloride. In each case, metals were added to concentrations equal to previously calculated half-maximal inhibition concentrations (IC50s) for the corresponding metal sulfates, or $0.94 \mathrm{mM}, 39 \mathrm{mM}$, and $120 \mathrm{mM}$, for lead, zinc, and copper, respectively. (b) Predicted and observed effect of chloride concentrations on the specific growth rate of A. caldus strain $\mathrm{BC} 13$ with zinc sulfate added to a concentration equal to either $50 \%$ or $100 \%$ of the previously calculated IC50 (39 mM). Similar results were observed with lead and copper (data not shown). Error bars represent $95 \%$ confidence intervals.

\section{Metal complexation and precipitation}

Visual MINTEQ predicted the complexation and potential precipitation of $\mathrm{Pb}, \mathrm{Zn}$, and $\mathrm{Cu}$ over the range of concentrations and combinations used in these experiments. The primary dissolved constituents of $\mathrm{Pb}, \mathrm{Zn}$, and $\mathrm{Cu}$ were aqueous divalent metal cations and metal sulfates, regardless of whether the metals were added as metal sulfates or metal chlorides. Lead was predicted to remain soluble up to a concentration of $20 \mu \mathrm{M}$. Concentrations used in these experiments were beyond this value, and visual precipitation of lead was observed. No precipitation was predicted or observed for $\mathrm{Zn}$ or $\mathrm{Cu}$.

Visual MINTEQ modeling results were entered into the multivariant statistical software MINITAB and compared against changes in the corresponding observed specific growth rates. Matrix plots and primary component analyses suggested that for all the metals, only changes in the total metal concentrations correlated strongly with changes in observed specific growth rates, and although speciation occurred, it did not significantly affect specific growth rates (data not shown).
Table 1. Toxicity of lead, zinc, and copper sulfates to Acidithiobacillus caldus strain BC13 described using the no observable effect concentration (NOEC), lowest observable effect concentration (LOEC), half-maximal inhibitory concentration (IC50), and the minimum inhibitory concentration $(\mathrm{MIC})^{\mathrm{a}}$

\begin{tabular}{lcccc}
\hline & NOEC $(\mathrm{mM})$ & LOEC $(\mathrm{mM})$ & IC50 & $(\mathrm{mM})$ \\
\hline Lead & 0.10 & 0.15 & $0.94 \pm 0.13$ & 7.5 \\
Zinc & 1.0 & 3.0 & $39 \pm 0.46$ & 75 \\
Copper & 5.0 & 10 & $120 \pm 8.2$ & 250 \\
\hline
\end{tabular}

${ }^{a}$ Inhibition was quantified by changes in the specific growth rate in the presence of metals. \pm Values indicate $95 \%$ confidence intervals.

\section{DISCUSSION}

Single toxicity of lead, zinc, and copper

The $\mathrm{BC} 13$ grew in millimolar concentrations of $\mathrm{Pb}, \mathrm{Zn}$, and $\mathrm{Cu}$, with $\mathrm{Pb}$ being the most toxic metal tested, having an MIC of $7.5 \mathrm{mM}$. Interestingly, A. caldus has not been isolated from environments containing high concentrations of galena [27], and results reported here suggest that these environments may contain $\mathrm{Pb}$ concentrations too high for significant $A$. caldus activity (Fig. 1a). The BC13 exhibited relatively high tolerances for $\mathrm{Zn}$ and $\mathrm{Cu}$, with MICs of 75 and $250 \mathrm{mM}$ (Fig. 1b and c). This is not surprising, because many of the environments in which $A$. caldus has been identified have high concentrations of $\mathrm{Zn}$ and $\mathrm{Cu}[4,27-29]$.

Previous work with A. caldus strain KU reported MIC values of $65 \mathrm{~g} / \mathrm{L}(993.9 \mathrm{mM})$ for $\mathrm{Zn}$ and only $1.5 \mathrm{~g} / \mathrm{L}(23.6 \mathrm{mM})$ for $\mathrm{Cu}$ [26], suggesting a Zn tolerance significantly higher than that observed here, and a $\mathrm{Cu}$ tolerance significantly lower. This previous work did not report methods for quantifying growth, or describe the growth medium used [26], making a direct comparison difficult. These differences may be attributable to strainto-strain variance in metal tolerance, medium composition, or possibly inoculum history. Regardless, $\mathrm{BC} 13$ and strain $\mathrm{KU}$ appear to be quite tolerant to $\mathrm{Zn}$ and $\mathrm{Cu}$.

\section{Comparisons with other acidithiobacilli}

High resistance to $\mathrm{Zn}$ and $\mathrm{Cu}$ is not unprecedented among the acidithiobacilli. Aside from previous work with A. caldus strain KU [26], Acidithiobacillus ferrooxidans has been observed to grow on ground $\mathrm{S}$ in a medium containing $100 \mathrm{mM} \mathrm{Cu}$ [30]. Furthermore, strain KU can facilitate sphalerite leaching in the presence of $25 \mathrm{mM} \mathrm{Zn}$ and chalcopyrite leaching in the presence of 10 to $25 \mathrm{~g} / \mathrm{L} \mathrm{Cu}(158-397 \mathrm{mM})$ [18,30]. Barreira et al. [16] and Chen et al. [17] made similar observations while working with $A$. thiooxidans.

With observed MIC values of $75 \mathrm{mM}$ and $250 \mathrm{mM}$ for $\mathrm{Zn}$ and $\mathrm{Cu}$, respectively, the current study suggests that $\mathrm{BC} 13$ has a level of tolerance to $\mathrm{Zn}$ and $\mathrm{Cu}$ similar to that of $\mathrm{A}$. ferrooxidans and A. thiooxidans. However, key differences can be seen between this work and previous work with acidithiobacilli. First, the current study used a soluble substrate (tetrathionate), which prevented the formation of biofilms that may provide some protection from metals [31], and second, the current study characterized toxicity directly with respect to cell growth, rather than inhibition of leaching kinetics.

\section{Effects of combined metals}

Metals presented in binary mixtures exhibited less than additive toxicity toward BC13, suggesting an aspect of competitive inhibition (Fig. 2). In addition, the significant decrease in $\mathrm{Pb}$ and $\mathrm{Zn}$ toxicity in the presence of ferrous iron (Fig. 3) is 
also quite interesting, given that many environments from which A. caldus has been isolated also contain high concentrations of Fe relevant to the concentrations used in the present study [4,27-29]. This suggests that BC13 may exhibit catabolic activity (leaching) in iron-rich environments with $\mathrm{Pb}, \mathrm{Zn}$, and $\mathrm{Cu}$ concentrations higher than the respective MIC values reported here. Previous studies also have observed less than additive toxicity in binary-metal systems. For example, Gikas [32] observed that $\mathrm{Ni}$ (II) and $\mathrm{Co}(\mathrm{II})$ exhibited similar individual toxicities to microbes growing in an activated sludge; however, when presented in combination, their toxicities were significantly reduced [32].

\section{Effect of inoculum history}

One aspect of cell culturing that is often overlooked in toxicity studies is inoculum history. In the current study, preadaption to $\mathrm{Pb}, \mathrm{Zn}$, or $\mathrm{Cu}$ increased specific growth rates of BC13 significantly when it was subsequently exposed to heavy metals (Fig. 4). Similar results have been observed by others [33-35] and may indicate higher tolerances in environments in which species have had prolonged exposure to metals.

Another aspect of inoculum history examined here was the effect of exposure to the MICs of $\mathrm{Pb}, \mathrm{Zn}$, and $\mathrm{Cu}$. Cells harvested from medium containing the MIC of $\mathrm{Pb}$ showed no residual effects, whereas cells harvested from media containing the MIC of $\mathrm{Zn}$ or $\mathrm{Cu}$ showed some residual effect but still grew quite well (Fig. 5), suggesting that $\mathrm{Pb}, \mathrm{Zn}$, and $\mathrm{Cu}$ may simply slow cell growth, perhaps through increased energy requirements. However, when cells were collected from MIC exposures to $\mathrm{Zn}$ or $\mathrm{Cu}$, they did not grow as well (Fig. 5). This may be because of residual metal strongly bound to the cells, as previous work has shown that $\mathrm{BC} 13$ has larger sorption capacities for $\mathrm{Zn}$ and $\mathrm{Cu}$ than for $\mathrm{Pb}$ [36]. The less than additive toxicities of $\mathrm{Pb}, \mathrm{Zn}$, and $\mathrm{Cu}$, and the ability of $\mathrm{BC} 13$ to be resuscitated from exposure to heavy-metal MICs, may suggest that cells are viable and metabolically active in environments containing $\mathrm{Pb}, \mathrm{Zn}$, or $\mathrm{Cu}$ concentrations significantly higher than the MICs observed here.

\section{Metal chloride versus metal sulfate toxicity}

Figure 6a shows the increased toxicity of metal chlorides over metal sulfates, and Figure $6 \mathrm{~b}$ suggests that this is attributable to additive toxicity, because additional experiments showed that chloride itself was inhibitory to BC13. This may explain why lead chloride toxicity was not significantly different from lead sulfate, because the corresponding chloride concentration was only $1.9 \mathrm{mM}$, which was not observed to be toxic when sodium chloride was added in the absence of $\mathrm{Pb}$, $\mathrm{Zn}$, or $\mathrm{Cu}$ (data not shown). Conversely, chloride concentrations associated with zinc and copper chlorides (78 and $240 \mathrm{mM}$ ) were toxic even in the absence of metals. This observation is supported by past work that reported chloride inhibition toward the acidithiobacilli [37], and although the chloride concentrations necessary to achieve this effect are not necessarily relevant to natural environments containing A. caldus [28,29], these results do emphasize the importance of metal salts chosen for inhibition studies.

\section{CONCLUSIONS}

To our knowledge, this is the first comprehensive report on $\mathrm{Pb}, \mathrm{Zn}$, and $\mathrm{Cu}$ toxicity to $\mathrm{A}$. caldus and the first study reporting the toxicity of $\mathrm{Pb}$ to any member of the acidithiobacilli. The order of toxicity observed here was $\mathrm{Cu}<\mathrm{Zn}<\mathrm{Pb}$, and the relatively high tolerances observed to $\mathrm{Zn}$ and $\mathrm{Cu}$ were comparable to those observed in other acidithiobacilli [16-18,30]. Additional studies using binary-metal mixtures and high ferrous iron concentrations were carried out to better relate the singlemetal toxicity observations to in situ realities. Interestingly, these studies suggested that binary-metal mixtures, and the presence of ferrous iron, significantly decreased the toxicity of $\mathrm{Pb}$ and $\mathrm{Zn}$ to $\mathrm{BC} 13$. In addition, inoculum history was an important factor in metal tolerance, because cells that were allowed to adapt to $\mathrm{Pb}, \mathrm{Zn}$, and $\mathrm{Cu}$ through subsequent culturing showed significantly increased tolerance to these metals. Combined, these results suggest that $\mathrm{BC} 13$ may grow and be metabolically active in environments containing $\mathrm{Pb}, \mathrm{Zn}$, or $\mathrm{Cu}$ concentrations higher than the MICs observed here when these metals were presented individually.

Finally, a comparison of metal sulfate versus metal chloride toxicity suggested that metal sulfates were much less toxic to BC13, because chloride ions exhibited an inhibitory effect of their own that was approximately additive with those of $\mathrm{Pb}, \mathrm{Zn}$, or $\mathrm{Cu}$.

Acidophilic chemolithoautotrophs play important roles in biomining and acid-mine drainage systems because of their tolerance and mobilization of metals [38-40]. The current study significantly improves the understanding of one such microorganism, A. caldus $\mathrm{BC} 13$, and may lead the way for future research of specific toxicity mechanisms and metal-regulated protein expression.

Acknowledgement-This work was supported by the Idaho National Laboratory Directed Research and Development program under Department of Energy Idaho Operations Office Contract DE-AC07-05ID14517, the National Science Foundation Montana Experimental Program to Stimulate Competitive Research (NSF), and the NSF Integrated Graduate Education Research Training, program (grant DGE-0654336). The authors also thank the Department of Chemical and Biological Engineering and Center for Biofilm Engineering at Montana State University for laboratory access and support.

\section{REFERENCES}

1. Hallberg KB, Lindstrom EB. 1994. Characterization of Thiobacillus caldus sp. Nov., a moderately thermophilic acidophile. Microbiology 140:3451-3456.

2. Dopson M, Lindstrom EB, Hallberg KB. 2002. ATP generation during reduced inorganic sulfur compound oxidation by Acidithiobacillus caldus is exclusively due to electron transport phosphorylation. Extremophiles 6:123-129.

3. Burton NP, Norris PR. 2000. Microbiology of acidic, geothermal springs of Montserrat: environmental rDNA analysis. Extremophiles 4:315-320.

4. Druschel GK, Baker BJ, Gihiring TM, Banfield JF. 2004. Acid mine drainage biogeochemistry at Iron Mountain, California. Geochem $T$ 5:12-32.

5. Goebel BM, Stackebrandt E. 1994. Cultural and phylogenetic analysis of mixed microbial populations found in natural and commercial bioleaching environments. Appl Environ Microbiol 60:1614-1621.

6. Okibe N, Gericke M, Hallberg KB, Johnson DB. 2003. Enumeration and characterization of acidophilic microorganisms isolated for a pilot plant stirred-tank bioleaching operation. Appl Environ Microbiol 69:19361943.

7. McGuire MM, Edwards KJ, Banfield JF, Hamers RJ. 2001. Kinetics, surface chemistry, and structural evolution of microbially mediated sulfide mineral dissolution. Geochem Geophy Geosyst 65:12431258.

8. Dopson M, Lindstrom EB. 1999. Potential role of Thiobacillus caldus in arsenopyrite bioleaching. Appl Environ Microbiol 65:36-40.

9. Zhou QG, Bo F, Bo ZH, Xi L, Jian G, Fei LF, Hau CH. 2007. Isolation of a strain of Acidithiobacillus caldus and its role in bioleaching of chalcopyrite. World J Microb Biotechnol 23:1217-1225.

10. Gadd GM, Griffiths AT. 1978. Microorganisms and heavy metal toxicity. Microbial Ecol 4:303-317.

11. Nies DH. 1999. Microbial heavy-metal resistance. Appl Microbiol Biotechnol 51:730-750. 
12. Nies DH. 2000. Heavy metal-resistant bacteria as extremophiles: Molecular physiology and biotechnological use of Ralstonia sp CH34. J Bacteriol 182:1390-1398.

13. Nies DH. 2003. Efflux-mediated heavy metal resistance in prokaryotes. FEMS Microbiol Rev 23:313-339.

14. Silver S. 1996. Bacterial resistance to toxic ions: A review. Gene 179:919.

15. Wood JM, Wang HK. 1983. Microbial resistance to heavy metals. Environ Sci Technol 17:582-590.

16. Barreira RPR, Villar LD, Garcia O. 2005. Tolerance to copper and zinc of Acidithiobacillus thiooxidans isolated from sewage sludge. World $J$ Microb Biotechnol 21:89-91.

17. Chen BY, Chen YW, Wu DJ, Cheng YC. 2003. Metal toxicity assessment upon indigenous Thiobacillus thiooxidans BC1. Environ Eng Sci 20:375-385.

18. Das A, Modak JM, Natarajan KA. 1997. Studies on multi-metal ion tolerance of Thiobacillus ferrooxidans. Miner Eng 10:743-749.

19. Leduc LG, Ferroni GD, Trevors JT. 1997. Resistance to heavy metals in different strains of Thiobacillus ferrooxidans. World J Microb Biotechnol 13:453-455.

20. Natarajan KA, Sudeesha K, Rao GR. 1994. Stability of copper tolerance in Thiobacillus ferrooxidans. A Van Leeuw J Microbiol 66:303-306.

21. Tuovinen OH. 1974. Studies on the growth of Thiobacillus ferrooxidans. II. Toxicity of uranium to growing cultures and tolerance conferred by mutation, other metal cations and EDTA. Arch Microbiol 95:153.

22. Hong-mei L, Jia-jun K. 2001. Influence of $\mathrm{Ni}^{2+}$ and $\mathrm{Mg}^{2+}$ on the growth and activity of $\mathrm{Cu}^{2+}$-adapted Thiobacillus ferrooxidans. Hydrometallurgy 61:151-156.

23. Dopson M, Lindstrom EB, Hallberg KB. 2001. Chromosomally encoded arsenical resistance of the moderately thermophilic acidophile Acidithiobacillus caldus. Extremophiles 5:247-255.

24. Kotze AA, Tuffin IM, Deane SM, Rawlings DE. 2006. Cloning and characterization of the chromosomal arsenic resistance genes from Acidithiobacillus caldus and enhanced arsenic resistance on conjugal transfer of ars genes located on transposon TnAtsArs. Microbiology 152:3551-3560.

25. Tuffin M, Hector SB, Deane SM, Rawlings DE. 2006. Resistance determinants of a highly arsenic-resistant strain of Leptospirillum feriphilum isolated from a commercial biooxidation tank. Appl Environ Microb 72:2247-2253.

26. Watkin ELJ, Keeling SE, Perrot FA, Shiers DW, Palmer ML, Watling HR. 2009. Metals tolerance in moderately thermophilic isolates from a spent copper sulfide heap, closely related to Acidithiobacillus caldus, Acidimicrobium ferrooxidans and Sulfobacillus thermosulfidooxidans. J Indust Microbiol Biotechnol 36:461-465.

27. Rawlings DE. 2002. Heavy metal mining using microbes. Аnnu Rev Microbiol 56:65-91.

28. Banks D, Younger PL, Arnesen RT, Iversen ER, Banks SB. 1997. Minewater chemistry: The good, the bad and the ugly. Environ Geol 32:157174.

29. Benner SG, Blowes DW, Gould WD, Herbert RB, Ptacek CJ. 1999. Geochemistry of a permeable reactive barrier for metals and acid mine drainage. Environ Sci Technol 33:2793-2799.

30. Alvarez S, Jerez C. 2004. Copper ions stimulate polyphosphate degradation and phosphate efflux in Acidithiobacillus ferrooxidans. Appl Environ Microb 70:5177-5182.

31. Xu KD, McFeters GA, Stewart PS. 2000. Biofilm resistance to antimicrobial agents. Microbiology 146:547-549.

32. Gikas P. 2007. Kinetic response of activated sludge to individual and joint nickel (Ni(II)) and cobalt (Co(II)): an isobolographic approach. J Hazard Mater 143:246-256.

33. Oorts KK. 2006. Discrepancy of the microbial response to elevated copper between freshly spiked and long-term contaminated soils. Environ Toxicol Chem 25:845-853.

34. Oorts KK. 2007. Leaching and aging decrease nickel toxicity to soil microbial processes in soils freshly spiked with nickel chloride. Environ Toxicol Chem 26:1130-1138.

35. Maderova L, Dawson JJC, Paton GI. 2009. Cu and Ni mobility and bioavailability in sequentially conditioned soils. Water Air Soil Pollut 210:63-73.

36. Aston JE, Apel WA, Lee BD, Peyton BM. Effects of cell condition, pH, and temperature on lead, zinc, and copper sorption to Acidithiobacillus caldus. J Hazard Mater, DOI: 10.1016/j.jhazmat.2010.07.110.

37. Kawabe Y, Chihiro I, Tadashi C. 2000. Relaxation of chloride inhibition on the biochemical activity of Thiobacillus ferrooxidans by Diatomaceous Earths. J Min Mat Proc Inst Japan 116:198-202.

38. Dopson M, Baker-Austin C, Koppineedi PR, Bond PL. 2003. Growth in sulfidic mineral environments: Metal resistance mechanisms in acidophilic microorganisms. Microbiology 149:1959-1970.

39. Gadd GM. 2000. Bioremedial potential of microbial mechanisms of metal mobilization and immobilization. Curr Opin Biotechnol 11:271279.

40. Veglio F, Beolchini F. 1997. Removal of metals by biosorption: A review. Hydrometallurgy 44:301-316. 